AUTHOR:

N. Assaf ${ }^{1}$

D. Gan ${ }^{1}$

AFFILIATION:

${ }^{1}$ The Kibbutzim College of

Education, Technology and the Arts, Israel

DOI: http://dx.doi. org/10.18820/2519593X/pie.v39.

i1.16

e-ISSN 2519-593X

Perspectives in Education

2021 39(1): 257-276

PUBLISHED:

12 March 2021

RECEIVED:

6 November 2020

ACCEPTED:

27 January 2021

\section{ENVIRONMENTAL EDUCATION USING DISTANCE LEARNING DURING THE COVID-19 LOCKDOWN IN ISRAEL}

\begin{abstract}
Education systems and environmental education professionals have been challenged by the COVID-19 pandemic and the sharp transition to distance learning that has necessitated a rapid response. Environmental education as part of a social-ecological system is dependent on the adaptability and the scope of the change with which the system responds to crisis. It is therefore important to explore the ways in which environmental educators choose to increase students' proximity to nature under conditions of lockdown. The aim of this study, therefore, was to examine environmental educators' perspective on and teaching methods for implementing environmental education under distance learning conditions. To this end, we conducted 16 interviews and analysed teaching methods (e.g. videos, lesson plans and written assignments) that were used by Israeli environmental educators in March-April 2020. The findings highlight the creativity of the educators who used a variety of teaching methods, involving active/ passive learning and the direct/indirect experience of nature, using nature for observation, investigation and in-depth personal, social and environmental learning. The study's contribution stems from its exploration of the crisis from the perspective of environmental education in the context of social-ecological systems. Key findings present challenges (e.g. lack of direct outdoor interaction and feedback) and opportunities (e.g. public access to online lectures and the nationwide sharing of teaching materials) that were faced by environmental educators in Israel and that led to the development of diverse teaching methods for contending with the crisis. The study recommends incorporating diverse activities in nature, implementing outdoor teacher training for all teachers and creating professional teacher networks.
\end{abstract}

Keywords: Social-ecological systems; adaptation; transformation; distance learning; environmental education; outdoor learning.

\section{INTRODUCTION AND THEORETICAL BACKGROUND}

As this article was being written, education systems and environmental educators were being challenged - as they often are during times of crisis (Kidman \& Chang, 2020) - by the lockdowns and uncertainty that have thus far stemmed from the COVID-19 pandemic. The upheaval that was caused to education systems by the sharp transition 
to distance learning has necessitated a rapid response. Indeed, after the health system, the educational system is the sector that has been most affected by the pandemic (Assunção \& Gago, 2020; Daniel, 2020; Hebebci et al., 2020; Huber \& Helm, 2020) because of the need to teach remotely instead of through face-to-face interactions, which is one of the most important roles of social, emotional and academic learning. The shortcomings of distance learning which include a lack of engagement in content learning, a lack of physical interaction with friends and a lack of immersion in the local environments (Azorín, 2020) - were even more prominent in the context of environmental education, in which the local outdoor environment plays a fundamental role. Research has found that students under lockdown conditions expressed their desire for the real learning that occurs during outdoor education (Quay et al., 2020). It is therefore important to explore environmental education in this situation.

The pandemic has the potential to bring change to educational approaches to environmental education. Environmental education is "concerned with developing an understanding of, and care for, the environment - social, cultural, built, natural - that occurs in the environment and through it" (Bonnett, 2013: 252). A complementary definition of environmental education refers to a holistic approach of four nested levels of ecologies: personal, social, environmental and cosmic. In this approach, environmental education should begin with individual health and well-being, move on to relationships with the community and ultimately address human-nature relationships (Wimberley, 2009). In other words, it should consider humans and the interactions of individuals as part of nature nested in larger social and environmental systems. As such, environmental education is viewed from an ecological perspective in which interactions among individuals, other humans and the biophysical environment surrounding them are nested in a larger programme that pertains to natural resource management practices and environmental policies (Tidball \& Krasny, 2011).

On the policy level, some countries - such as in Finland (Sjöblom \& Svens, 2019), Scotland (Perlman et al., 2020) and Australia (Passy et al., 2019) - have implemented environmental education as their core standards. In Israel, environmental education is not a major requirement of the public school curriculum. Official policy calls for incorporating it into all subject matter, but in reality, only teachers and schools that are interested in environmental education actually employ it. As a result, few schools have implemented environmental education in an extensive manner. In many schools, the "green" remains mainly on the surface (Tal, 2020), meaning that students are not systematically exposed to the ideas of environmental education and that preservice teachers are not obligated to study it (Sagy \& Tal, 2015). For this reason, it is important to study the perspectives of environmental educators, who do implement it in this context.

According to the nested-ecology approach, environmental education integrated into social-ecological frameworks should be considered as part of a larger system, contributing to the understanding of dynamic processes and feedback in the nested systems (e.g. individual ecology, social ecology and environmental ecology, which includes the non-human aspect of the system). Such an analysis may contribute to environmental education, to broader system management practices and to decision making in the realm of policy (McPhearson \& Tidball, 2013).

The pandemic sparked a global reaction that involved the influencing of policy makers, changing education systems and shifting environmental resource management practices (Quay et al., 2020). These different levels of change (the local, the national and the international) make the social-ecological system approach, and environmental education as 
part of it, well suited as a framework for this study. To understand the Israeli situation regarding the implementation of environmental education during lockdown, this study examined the responses of professionals engaged in the field. Environmental education using the socialecological systems approach (Leal Filho et al., 2018; Plummer, 2013; Sterling, 2010) is rarely used as an analytical framework for the education arena (Colding \& Barthel, 2019; Krasny et al., 2015; Tidball \& Krasny, 2011; Krasny \& Roth, 2010; Krasny \& Tidball, 2009). However, such use stands to contribute to a broader global analysis of environmental education and its relationship with the diverse levels of nested ecologies (i.e. individual, social, environmental, and cosmic) (Krasny et al., 2015). In this way, it can spark a discussion on the role of environmental education in enhancement, adaptation, resilience and process promotion in systems (Krasny \& Tidball, 2009).

Social-ecological systems are complex systems with influence that varies across time and space (Folke et al., 2010; Krasny \& Tidball, 2009; Tidball \& Krasny, 2010; Walker et al., 2004). They deal with the mutual relations between humans and nature and are characterised by three primary attributes: resilience, adaptation, and transformation. These attributes provide stability to the processes that occur in the system. Social-ecological systems are impacted by: pulses (one-time disruptions) and stresses (ongoing disruptions) (Folke et al., 2010; Löf, 2010; Walker et al., 2004). The COVID-19 pandemic is an example of a quick pulse that has had an extreme impact on the social-ecological system, including the field of environmental education. The social-ecological system's response to the crisis surrounding the pandemic is related to resilience, which depends on the adaptation and the transformation with which the system responds to the disruption (Folke et al., 2010). Resilience is a measure of a system's ability to contain disruptions so that the process of change results in reorganisation. Resilience is measured by a system's ability to maintain its role with regard to structure, identity and the provision of feedback - that is to say, to be maintained as a sustainable system (Plummer, 2013).

This raises the question of the level of resilience characterising the social-ecological system and therefore the degree to which it will be able to adapt to crises and then to return to its previous state - or, in other words, the extent to which it will perform single-loop learning. Single-loop learning is a form of specific learning with minor adaptations in light of errors (Plummer, 2013). For example, during the COVID-19 pandemic, environmental education has been able to shift to online teaching about nature-related topics without using the outdoors (Quay et al., 2020). The system's response can also occur through double-loop learning and attempts to change organisational norms (Löf, 2010). For example, the education system has been able to afford teachers greater autonomy during the COVID-19 crisis than during times of normalcy and can continue doing so in the future (Quay et al., 2020). Research has shown that even in times of normalcy, teachers with a sense of autonomy demonstrate positive relationships with their students as well as greater adaptability, which has been found to be extremely important during the pandemic (Collie \& Martin, 2020; Reimers \& Schleicher, 2020).

The crisis could also cause a fundamental change, or transformation, that reshapes the social-ecological system, including the education system and environmental education. This is triple-loop learning, which results in fundamental change to the model of organisational management (Löf, 2010). In other words, the question is whether the crisis will serve to advance environmental education as part of the conception of social-ecological systems of assimilation within the education system. Such environmental education is based on partnership in sourcecontingent and context-contingent teaching and learning; interdisciplinary systemic teaching in 
the environmental and social context of the learners and teaching conducted in a sustainable experiential-holistic manner, aimed at a perception and behavioural change toward society and the environment and relating to the social-ecological system on all of its levels (Leal Filho et al., 2018; Plummer, 2013; Sterling, 2010). In triple-loop learning, environmental education, as part of the conception of the social-ecological system, can serve as a primary tool for effecting change in society and in the environment, and, in this way, it can also impact the education system as a whole (Leal Filho et al., 2018).

Environmental education in the context of the social-ecological systems approach has been explored in diverse environments. For example, Krasny and Tidball (2009) studied urban environmental education using community gardens as a model for addressing social and ecological concerns. They found that the bio-diversity, the diversity in knowledge, and the selforganisation reflected in the planting of gardens led to eco-system services and community participation, and, as a result, contributed to a sense of social connection and the resilience of social-ecological urban systems. Other examples used the frame of resilience in socialecological systems to emphasise environmental education as an instrumental process that includes problem solving to illustrate first-loop learning, and environmental education as an intrinsic process emphasising reflection to demonstrate second-loop learning (Sterling, 2010).

In light of these facts, this study is unique in its objective of examining the behaviour of environmental educators during the crisis period when it was almost impossible to go outside. Such an inquiry can reveal if a change occurred, but it cannot tell us whether the change was the result of single-loop learning after which the situation would return to what is familiar to us or whether it created a new reality. Based on the concept of social-ecological systems, environmental education incorporates the outdoors through its dependence on the context of place, environment and society (Krasny \& Roth, 2010) and its emphasis on experiential learning (Kolb, 2014) in the environment (Krogh \& Jolly, 2012). These aspects are a meaningful part of creating social-ecological systems and developing critical thought that enables intelligent action for the environment and for society (Sterling, 2010; Tidball \& Krasny, 2011). The second objective of the study is to examine the ways in which environmental educators have chosen to empower the location of nature as part of their educational conception, in an attempt to find ways to bring people closer to nature while locked down in their homes. This is a topic that has not been addressed extensively by the literature (Kidman \& Chang, 2020). To investigate it further, we asked the following two questions: (1) How can we characterise the teaching methods that were employed by environmental educators during the COVID-19 lockdown? And (2) How, from the perspective of environmental educators, are the teaching methods they employed related to past experience, and how can they contribute to teaching in the future?

\section{METHODOLOGY}

In this interpretive qualitative study, we considered social-ecological systems on three levels: the global, the national and the local. The study examined Israeli educators contending with the beginning of the pulse at a unique point in time, in March 2020, during the Israeli education system's transition to distance learning due to the COVID-19 pandemic. The data was collected over a period of five weeks, from the beginning of Israel's first lockdown until the end of Passover vacation (April 2020). 


\subsection{Participants}

All the participants were academically educated (most hold a Master's degree), and the majority were educated in the field of environmental education, with an average of 16 years of experience in the education system. The study participants have a variety of subjects of expertise: science, art, the environmental sciences, and work with a variety of age groups (preschool, elementary school, middle school, high school and special education) (Table 1). The study participants constituted a goal-oriented convenience sample, contingent on the participants' availability to the researcher (Creswell, 2012). We sent emails to approximately 30 education professionals who engaged in environmental education on a regular basis during times of normalcy and under lockdown, and who were willing to participate in the study. The resulting sample is not representative of the Israeli education system but presents the unique perspective of individuals who have been educated and area experienced in the field of environmental education.

We interviewed 16 educators - those who agreed to take part in the study. In the interview, they were asked questions pertaining to their personal background and to approaches to environmental education. To understand the teaching methods that were employed by the interviewees, they were asked questions such as: In what ways do you manage to incorporate aspects of environmental education during lockdown? Give examples of things you have done and responses you have received from children, their parents and colleagues. What is the main thing at which you feel you succeeded during this period and what do you think will happen in the future? This article presents only some of the findings of a larger study on the subject.

Table 1. The study participants

\begin{tabular}{|l|l|l|l|}
\hline No. & Position & $\begin{array}{l}\text { Years of } \\
\text { seniority }\end{array}$ & Education \\
\hline 1 & Preschool teacher (ages 3-5) & 25 & $\begin{array}{l}\text { Master's Degree: } \\
\text { Environ. Ed. }\end{array}$ \\
\hline 2 & $\begin{array}{l}\text { Science coordinator and teacher, mentor } \\
\text { (elementary school) }\end{array}$ & 20 & $\begin{array}{l}\text { Master's Degree: } \\
\text { Geology }\end{array}$ \\
\hline 3 & Preschool teacher (ages 3-6) & 23 & $\begin{array}{l}\text { Master's Degree: } \\
\text { Environ. Ed. }\end{array}$ \\
\hline 4 & $\begin{array}{l}\text { Preschool teacher (ages 4-6) } \\
\text { (elemce teacher and homeroom teacher (post- } \\
\text { primary school) }\end{array}$ & 25 & $\begin{array}{l}\text { Bachelor's Degree: } \\
\text { Teaching Education }\end{array}$ \\
\hline 6 & $\begin{array}{l}\text { Nature and science teacher (elementary and post- } \\
\text { primary schools) }\end{array}$ & 3 & $\begin{array}{l}\text { Bachelor's Degree: } \\
\text { Teaching Biology }\end{array}$ \\
\hline 7 & $\begin{array}{l}\text { Art and environmental education teacher } \\
\text { (elementary school) }\end{array}$ & $\begin{array}{l}\text { Bachelor's Degree: } \\
\text { Teaching Biology }\end{array}$ \\
\hline 8 & Preschool teacher (ages 3-5) & $\begin{array}{l}\text { Master's Degree: } \\
\text { Environ. Ed. }\end{array}$ \\
\hline 9 & $\begin{array}{l}\text { Preschool teacher and preschool teacher instructor } \\
\text { (ages 3-5) }\end{array}$ & 11 & $\begin{array}{l}\text { Master's Degree: } \\
\text { Environ. Ed. }\end{array}$ \\
\hline 10 & $\begin{array}{l}\text { Special education science teacher (ages 6-21) } \\
\text { Preschool teacher (ages 3-5) }\end{array}$ & 28 & $\begin{array}{l}\text { Master's Degree: } \\
\text { Environ. Ed. }\end{array}$ \\
\hline 11 & Environ. Ed. \\
\hline
\end{tabular}




\begin{tabular}{|l|l|l|l|}
\hline No. & Position & $\begin{array}{l}\text { Years of } \\
\text { seniority }\end{array}$ & Education \\
\hline 13 & Art teacher (elementary school) & 15 & Master's Degree: Art \\
\hline 14 & Environmental science teacher & 5 & $\begin{array}{l}\text { Master's Degree: } \\
\text { Environ. Ed. }\end{array}$ \\
\hline 15 & $\begin{array}{l}\text { Science and special education teacher (middle and } \\
\text { high school) }\end{array}$ & 15 & $\begin{array}{l}\text { Master's Degree: } \\
\text { Environ. Ed. }\end{array}$ \\
\hline 16 & $\begin{array}{l}\text { Preschool teacher, preschool teacher instructor, } \\
\text { director of centre for science and environmental } \\
\text { education }\end{array}$ & 28 & $\begin{array}{l}\text { Master's Degree: } \\
\text { Environ. Ed. }\end{array}$ \\
\hline & $\begin{array}{l}\text { Total: } 7 \text { preschool teachers; } 9 \text { teachers (6 } \\
\text { elementary school and 3 post-primary) }\end{array}$ & Avg. $=16$ & \\
\hline
\end{tabular}

\subsection{Research tools and data analysis}

Semi-structured interviews - inductive analysis: In this study, we applied inductive analysis (Fereday \& Muir-Cochrane, 2006) to semi-structured interviews (Seidman, 2012) that were conducted through phone and the Zoom application and that were recorded and transcribed. The interviews were conducted with 16 participants who engaged in environmental education as an integral part of their teaching in times of normalcy as well as in times of crisis - as in the case of the COVID-19 pandemic that necessitated distance learning.

The data analysis consisted of three stages (Miles \& Huberman, 1994): (1) naïve reading of the interview; (2) organisation of the data through first cycle coding and second cycle coding (Saldaña, 2009) and (3) the creation of categories through the aggregation of main topics. The interviews were analysed individually by each of the two researchers who are experts in the field of environmental education and a comparison was conducted to establish agreement and triangulation (Denzin \& Lincoln, 2011).

Analysis of documents and teaching methods: At the same time, the teaching methods that were used by the participants were analysed based on the interviews, teaching methods (such as PowerPoint presentations and videos) and documents (lesson plans, pictures, games and written assignments) that were sent by email, WhatsApp and other digital means before and after the interviews. The teaching methods were counted by type, for example: lectures, films and outdoor assignments. In total, 16 teaching method types were identified with some appearing more than once (films, lectures, etc.). These types encompassed a total of 38 teaching methods. An analysis that characterised the teaching methods according to the learners' level of activeness and to the level of direct or indirect interaction with nature led to the division of teaching methods into three groups: 1) active learning and direct experience with nature; 2) active learning and indirect experience with nature; 3) passive learning and indirect experience with nature. For each group, the prevalence among all the teaching methods was calculated $(n=38)$.

Deductive analysis according to the literature: Another analysis applied to the interviews and to the teaching methods that were assembled was based on deductive analysis according to the theory of social-ecological systems, which refers to three loops of learning: single-loop learning, double-loop learning and triple-loop learning. Each loop was characterised on a scale of participants and space. Also examined were the educational processes that occurred in each of the loops during the period in question, the challenges and opportunities that the situation posed to out-of-classroom teaching and homeroom education in particular, as viewed by the environmental educators who took part in the study. 
The study was conducted in accordance with the relevant ethical considerations. A request to conduct the research was submitted to the Institutional Review Board (IRB) and contained all the necessary information about goals, significance, methods and participants (Creswell, 2012). To protect the privacy of participants and to increase the confidentiality of the research, the data were administered using encrypted secure data storage and by assigning pseudonyms to participants. Limited access to this data (only the researchers had access) further enhanced privacy and confidentiality, all audiotapes were destroyed and all identifying information remained confidential. Other data will be safely destroyed after the passage of a reasonable amount of time. An email was sent out to participants explaining the study and its goals and asking for cooperation and permission to conduct it. Participants took part in the study voluntarily and were informed of their right to cease doing so at any time if they felt uncomfortable. Additionally, no incentives were offered to participants. An informed consent form developed for the study explained the details of the study, its importance, how data would be collected, managed and stored and steps taken to ensure confidentiality, protection of privacy and the right of participants to withdraw from the study at any time. Participants signed the consent form and verbally agreed to participate in the study.

\section{FINDINGS}

The analysis of the data (documents and interviews) facilitated an examination of teaching methods ( $n=38$ ) and learning environments (outdoors and at home), in accordance with the learner's level of activeness and his or her direct or indirect experience in nature. Three kinds of learning experiences were identified: (1) Active learning and direct experience of nature $(26 \%)$ - Activity requiring that the learner be active outdoors and take advantage of the opportunities offered by nature and the environment; for example, sending children outside to photograph and collect flowers in order to learn about and observe them; listening to the sounds of birds and nature outdoors; writing with materials collected outdoors; painting natural elements such as the sky, flowers or birds after observing them and picking herbs for making tea. (2) Active learning and indirect experience of nature (26\%) - Learning that occurs in the home, during which learners used technology or materials that can be found at home without direct engagement with nature or the environment but rather through mediation, such as: solving brainteasers about plants and animals, making things out of recycled materials, building nest boxes for birds and creating an online collection of students' products made out of diverse materials. And (3) passive learning and indirect experience of nature $(47 \%)$ - Activity in which the learner is passive and views natural phenomena online, meaning that the learner is not physically present or is looking out a window at outdoor phenomena. For example, watching videos and taking part in Zoom meetings on topics pertaining to nature and the environment. It was discovered that the teachers used active learning outdoors $(26 \%)$ to the same extent that they used active learning indoors (26\%). Thus, even if there was no direct interaction with nature as part of the activity, $52 \%$ of the learning involved experience.

The findings of the interviews' analysis that are characteristic of social-ecological systems found expression in three categories on three levels: (1) single-loop learning; (2) double-loop learning and (3) triple-loop learning.

\subsection{Single-loop learning: Small-scale and quick, locally specific}

This category refers to quick small-scale loop learning in which the environmental educators used diverse teaching methods that enabled them to incorporate nature and the environment 
into the learning process while adapting to the feedback of the learners and their parents. The single loop reflects the initial response of the system and is indicative of specific local learning (within the permitted distance of up to 100 metres from home).

Characteristics of the single-loop learning: In this loop, the educators mentioned the different actors that were involved in distance learning during lockdown: parents, students and the environmental educators themselves. Several interactions between the actors were identified by the educators, such as greater parental involvement in students' distance learning and the different relationships between teachers and students that required different communication strategies. This learning also involved the home environment, with its many different elements, up to a distance of 100 metres from the home. The major educational characteristics included the rapid impact of the COVID-19 crisis, which included a sharp transition to online learning. These extremely quick processes were sensitive to needs on the ground and responded to developments on the ground accordingly.

These characteristics influenced the categories that emerged from data analysis. The lockdown created the need to integrate nature into learning, resulting in a sense of connection to nature and generating the need to integrate technology into learning. The new situation was met with diverse feedback from students and parents and all of these experiences caused us to think seriously about continuity - that is, the use of past experience and the teaching of methods of the future.

\section{A sense of connection to nature}

The environmental educators were concerned about the possibilities for incorporating nature experiences into learning and into their teaching during lockdown. As explained by one preschool teacher:

We succeeded in maintaining the children's wonder, curiosity, and sense of closeness to nature in different ways... despite the fact that....we are not exactly out in nature and cannot see...the petals of [the chrysanthemum] close up because evening has fallen... we can [look outside with parental supervision], imagine, or watch short movies about it.

This quote demonstrates the importance of the sense of connection to nature that all participants emphasised as well as the manner in which they used educational principles, such as the creation of wonder in students through a variety of teaching methods. Another teacher, this time in elementary school, used more sophisticated methods to create a sense of connection to nature:

We suggested to them [the students] to contemplate nature through the window or within the permitted distance...to choose a framework...through which they could see the sky and the trees...We asked them to photograph the special things they saw...out of... listening to and experiencing the environment.

This quote illustrates the encouragement of active learning through the observance of nature and self-contemplation. All participants used creative methods to help establish a sense of connection to nature among students that helped overcome the challenges of not being together outdoors. The educators were able to generate meaningful activities grounded in the context of place, society and environment, while encouraging parents to help their children spend time outdoors in nature near their homes. All of this reflects principles of environmental education according to the social-environmental systems approach. 


\section{Integrating technology into learning}

The need to integrate technology into learning while under lockdown conditions changed the approach of most early childhood educators to the subject. Prior to the pandemic, these educators made little to no use of technology for teaching in school and preferred being outdoors with the students and experiencing nature with all of their senses. Their approach to the subject changed because of their experiences during distance learning, as one pre-school teacher explained:

[Today] I want to have technology, because I discovered that this is a tool that can be used... [It allows us to see] things that are not in our immediate surroundings...like a video of a glacier... or how a plant grows ... [which is a phenomenon] that I cannot show in school.

This quote reflects an understanding of the advantages of technology that can contribute to learning and understanding natural phenomena and not necessarily harm the learning process. Another teacher emphasised the use of media and screens "because it is not always possible to go outdoors...but [we can] bring the outdoors to the screen...I used media to incorporate the principles... of sustainability and environmental education." This was another way the teachers succeeded in maintaining environmental education under lockdown according to the social-ecological systems approach. In other words, technology facilitates environmental education that incorporates interdisciplinary systemic teaching indoors and outdoors.

\section{Feedback from students and parents}

One of the challenges faced by all teachers was the lack of direct feedback from their students about their feelings, their learning and their understanding. The teachers were surprised from the feedback they received from their students when they asked them to take photos outdoors and to describe the nature in their immediate surroundings, as one elementary teacher emphasised: "This is one of the most amazing things that happened...Many students sent photos they took, and this was excellent feedback." The teachers wanted to connect students to nature and received reactions that helped them better understand the learning and emotional processes of students. Another teacher was surprised by the observation skills of their students:

[The children] asked me... about something in the video...that I sent, which I had not even noticed. That is to say, they looked ... [In this way] I am able to touch them and teach them....and I am able to be with them.

This pre-school teacher felt that nature experiences enabled her to feel close to her students, even though they were conducted in the context of distance learning. Another preschool teacher also expressed a sense of closeness to her students: "I have been receiving photos of beetles [from the students]... When they send them to me, I know that I touched them." This feeling of psychological touch replaces the real physical connection between students and educators. Feedback also included parental involvement in the teaching and learning processes, as noted by one of the middle school teachers: "Seventh graders...did mother-daughter yoga lessons for one another, and a father-son history lesson." Parents were also involved in experiencing nature with their children. All of these quotes represent the principles of environmental education according to the social-ecological systems approach in which nature can facilitate partnership in teaching and learning, even in a lockdown situation. 


\section{Continuity: Using past experience and considering future teaching methods}

The environmental educators created an educational process that began before the lockdown and has the potential to continue after it. All teachers used their experiences with their students. For example, one elementary school teacher pointed out, "I continued the topic we were studying [before the lockdown] - geophytes. Everyone buried it in the shade of a daffodil they took home and monitored it." This representative quote reflects the creativity and flexibility of the teachers who found ways to engage students learning about natural phenomena in an ongoing manner. The teachers tried to create a process they started in the classroom even though they did not know what would happen. Another example of this continuum was described by an elementary school teacher as follows: "I sent an app of bird calls along with quizzes. They liked the activity because it was like things we've done....in class...They will never forget the birds from this period." These quotes demonstrate the use of diverse senses (listening, observing and feeling touch) that teachers had encouraged their students to use. The students had experienced these types of activities before and were therefore able to repeat it without the physical presence of their teachers.

As reflected in the following quote of a pre-school teacher, participants in this study understood that all their new teaching experiences,

must be maintained... when we return to normalcy. It cannot... return to what used to be... learning can occur in other ways. [We] need to stop, to think outside the box, to not think about the familiar, and to venture out of our comfort zone (preschool teacher).

Teachers expressed their eagerness to reconnect students to nature. In the words of another pre-school teacher:

The first week after we return [after lockdown]...we will be in the forest. We will not be in the kindergarten at all. Because in the forest we are not concerned with materialism or with games and toys. We are concerned with being one with nature.

The environmental educators emphasised the creation of meaning grounded in the context of place, nature and environment, which are part of the principles of environmental education according to the social-ecological systems approach.

It was evident that the environmental educators encountered various challenges, including the difficulty of mediating outdoor learning without being able to go outdoors to observe natural phenomena as a group and the need among younger students for adult supervision. Furthermore, the teachers looked for feedback from the students, which is evident in faceto-face contact but may prove challenging in distance learning. Another challenge was the blurring of the boundaries between parents and teachers, especially in the younger students, but in older students as well. These challenges created opportunities for generating positive thinking about nature and the surrounding environment while incorporating nature into teaching in a creative and diverse manner. The feedback from the students facilitated an individual emotional connection with the educators due to the unique situation that enabled teachers to be in closer personal contact with the students. In addition, the educators suggested it encouraged parental learning about issues pertaining to nature and the environment stemming from the children's interests and the diverse outdoor activities. 


\subsection{Double-loop learning: Medium-scale, national}

The double-loop learning, which can be characterised as "medium" in scale and duration, dealt with learning about the national decision-making level of the Ministry of Education, as perceived by the study participants. The relatively slow reaction of the Ministry of Education afforded autonomy to environmental educators, who viewed this development in a positive light. This autonomy resulted in creativity and the extensive use of films and lectures that were made accessible to the public by national institutions of education, culture and the environment.

Characteristics of the double-loop learning: In this loop, study participants mentioned national influences that related to policy makers, the Ministry of Education, Israeli culture and environmental organisations. The educators discussed the nationwide state of being unable to go outside and explore nature reserves but at the same time developed the public understanding of what happened to nature reserves and nature in the city during a lockdown. Participants mentioned a decline in air pollution and a revival among animals in Israel's natural environments due to the lockdown. Double-loop learning is also characterised by educational opportunities such as public access to online lectures and the national sharing of teaching materials. On this national level, participants emphasised the slow processes in the education system; it did not keep up with the pace of activity on the ground, which occurred too late, and in some cases served to disrupt the activity on the ground. This learning loop was influenced by social media-based cooperation within and among groups in society and especially among educators.

\section{Autonomy}

The environmental educators were pleased by the autonomy they received from the Ministry of Education, as one high school teacher pointed out: "The principals on the ground are completely autonomous, which is nice." This was an abnormal situation in Israel's centralised education system with its strong evaluative trend that usually puts pressure on middle and high school teachers to teach specifically for tests. Regarding herself and other teachers, one teacher said,

[l] must say...thank you to the Ministry of Education...From teachers and principals alike...We received a policy of engaging in education. [But] they do not drop plans in on us...We are starting to create a new kind of learning.

This quote reflects the highly hierarchal structure of the Israeli education system in which every education minister develops new policies and changes the focus of the entire system by assigning additional tasks to teachers. Israel's Ministry of Education was not ready for COVID-19 and as one high school teacher noted:

The COVID-19 situation accentuated the "holes" in the education system...such as the number of students [too many] in the classroom...It created chaos in the Ministry of Education...there is no leadership...no orders...they didn't do anything.

This quote illustrates the transition from an organised hierarchical education system to a chaotic situation. The environmental educators were pleased to have the opportunity to integrate environmental education whenever they liked. The autonomy they were given enabled them to be creative and flexible. 
This chaotic situation caused participants to hope that environmental education would receive greater acknowledgment from the Ministry of Education. In the words of one middle school teacher: "I hope the Ministry of Education will appreciate environmental education... and will encourage teachers to go outdoors and to appreciate the nature and the environment that surrounds us." This quote is reflective of the situation in Israel, where environmental education is not a core subject and suffers from a lack of appreciation and support. The educators interviewed reflect a holistic approach to environmental education that facilitates a termination of the hierarchy as well as a joint effort in producing learning and teaching in the environmental and social context. This reflects the principles of environmental education according to the social-environmental systems approach.

\section{Environment and nature in israel and teaching materials}

Participants in this study acknowledged the positive impact of lockdown conditions on the environment on a nationwide level. In the words of one educator: "The sky is now bluer...I can hear birds more often than usual...People understand the effect of pollution on the environment...and the positive effect of Coronavirus on the environment." This quote reflects an understanding of the human-nature relationship that emerged under lockdown. Other participants stressed the pandemic's capacity as "a mirror for our society". Their understanding of natural phenomena under lockdown conditions encouraged the educators to teach their students about environmental education. Environmental educators, in turn, used the national materials that were published by nature organisations that reflected nature in Israel under lockdown.

In the double-loop learning, the educators articulated challenges and opportunities regarding environmental education during the COVID-19 pandemic. The transition from an orderly system to a chaotic system initially was a challenge for environmental educators, as it was for the entire system. However, this challenge also provided an opportunity for the study participants, who used the autonomy that was created by the vacuum left by the chaotic situation. They used films and presentations of natural phenomena occurring during the COVID-19 period as one educational method for teaching their students about humannature relationships and presenting nature and its rehabilitation without humans.

\subsection{Triple-loop learning: Large-scale, slow and international}

In the large-scale but slower triple-loop learning process, we identified learning on the global level as perceived by the environmental educators in the context of their personal learning about issues of environment and nature from elsewhere in the world. At the time the study was conducted, the full scope and nature of triple-loop learning was still not sufficiently clear.

Characteristics of the triple-loop learning: Participants noted the global influences of the pandemic caused by diverse occurrences such as the cessation of automobile and air travel, about which they learnt from the international media and the global social media. However, they were not certain about the global impact of the COVID-19 pandemic in general and on environmental education in particular, and they were unclear on what they could learn at this level and at the point in time when the study was being conducted. Participants mentioned the environmental aspects attributed on a global level, such as decreased air pollution and other natural phenomena. They emphasised the new access to teaching material from around the world and the ability to learn from other countries that quickly researched and took action in the field of education. The environmental educators acknowledged the situation's global 
impact on the environment, as one teacher explained, "The global situation of the COVID-19 pandemic creates awareness of the environment and of nature everywhere." Participants also stressed the need to "work globally... to create impact on decision makers". Although, there is some evidence related to the global phenomena, it was limited due to the time at which the study was undertaken.

\section{Internationalism}

Several participants mentioned the global influence on their own environmental engagement. According to one pre-school teacher:

I went into environmentalist groups on Facebook and groups on education from around the world...into UNESCO...to see what they were writing...We are a global village, and we can take things from there and bring them here. You may be closed up inside a room, but you have access to the entire world.

This quote reflects the opportunities the educators used to protect the environment and acknowledges the diverse possibilities presented by being part of global groups. We might say that the feeling of being locked down encouraged participants to embrace a broader perspective on the world through the internet, even though it is not written in their native language. Looking for materials and for global groups needs to occur in English, which is not common among educators in times of normalcy. The language barrier usually prevents Israeli teachers from using educational materials that are posted on the internet. However, the global experience enhanced interdisciplinary learning on the part of the educators and then incorporated their new understanding into their teaching approach and methods. This is consistent with the principles of environmental education according to the social-environmental systems approach in that it relates to all levels of influence, from the local to the national to the global.

The study's findings suggest that environmental educators used the challenge of lockdown to engage in triple-loop learning that created opportunities such as the rediscovery of nature in the world, as opposed to focus on fear of the virus. The educators also used diverse teaching methods from around the world. Indeed, it was the isolation and lockdown as well as the time they created that enabled educators to learn on a global level. These challenges and opportunities have been part of environmental education during the COVID-19 pandemic as perceived by the study participants, in light of the triple learning-loop analysis of socialecological systems.

\section{DISCUSSION}

Regarding the question dealing with the characterisation of the teaching methods that were implemented by environmental educators, substantial diversity was found to exist in the online and the outdoor teaching environments as well as in the manner in which the environmental education was implemented. The environmental educators testified that the use of technology during the crisis helped them incorporate as opposed to abandon environmental content, despite the challenges. Consistent with previous studies, the present study indicates that, according to environmental educators, there are also advantages to incorporating technology into learning in the context of environmental education (Altomonte et al., 2016). In addition, it indicates that in contending with the situation that arose during the COVID-19 crisis, educators succeeded in striking a balance between the use of technology and the limited use of nature and the environment that was possible at the time. 
Through distance learning that incorporated nature and the environment, the environmental educators demonstrated creative thinking and substantial flexibility, the latter of which, according to the literature, is a required skill for developing creativity (Jauhariyah et al., 2019). The environmental educators we interviewed are also in need of flexibility and creativity when teaching outdoors in times of normalcy, due to the need to adapt their teaching to unanticipated developments (Tal et al., 2014) and the need to mediate to students the changes involved in the environmental crisis (Leal Filho et al., 2018; Sammalisto et al., 2015). In accordance with the feedback that the environmental educators received from the students and their parents, the present study attests to diverse abilities that also resulted in meaningful learning at home.

In response to the research question regarding the environmental educators' perception of the teaching methods they used in the past and their contribution to teaching in the future, we employed the theory of social-ecological systems and learning loops, which characterises response to change in these systems as part of the concept of resilience (Löf, 2010). An analysis of the teaching methods that were used by the environmental educators indicates an initial response of the system through small-scale and quick single-loop learning. The environmental educators used their knowledge of nature and the environment and their capacity to guide students to engage in work at home on their own or with the assistance of their parents.

Analysis of the scales of loop learning suggests that processes of change relating to local, national and global educational processes occurred, as described by the environmental educators. As we can see, the educators who are part of the social-ecological system placed special emphasis on the processes related to single-loop learning (on the local level of teachers, students and parents), and less on processes of double- (on the national level of policy makers and organisations) and triple-loop learning (on the global level). This occurred in part, as a result, of the quick response that was characteristic of the single-loop learning, which was local adaptations of environmental education to the radical change that had occurred (the pulse of the COVID-19 pandemic).

At the stage at which the study was conducted, the situation had been adapted to on the level of single-loop learning, but much less on the level of double- and triple-loop learning. Deep change requires triple-loop learning (Löf, 2010), which is not reflected in this study and may occur in the future. That is to say, achieving change in the social-ecological system that impacts environmental education requires global change. For example, reducing the importance of international tests on the global level could help decrease their importance on the national level in Israel (Pizmony-Levy, 2018), which could help educators assimilate environmental education as it was implemented during the crisis when they were afforded autonomy. This study has several limitations, including its focused and unique point in time, its relatively small sample and its occurrence in Israel, which does not regard environmental education as a core subject. To overcome the limitations of the study, which was conducted during the brief initial period of coping with distance learning, an effort should be made to examine the issue over time and to increase the number of interviewees in Israel and worldwide. Perhaps change will occur over time, when online learning increases or decreases in strength. If this occurs, follow-up studies will be required to examine the continuation of this change in the education system as a whole on larger geographical, chronological and disciplinary scales. 
The study participants testified that in the future, use will also be made of the teaching methods they developed and the learning process they experienced in times of normalcy. They were visibly surprised by the advantages that technology facilitated in teaching environmental education and in creating an experience relating to the field that the literature describes as place- and context-contingent and implemented in a holistic manner (Leal Filho et al., 2018; Plummer, 2013; Sterling, 2010). In actuality, the technology not only did no harm but rather also contributed to the implementation of environmental education.

\section{RECOMMENDATIONS AND CONCLUSIONS}

The findings of the study resulted in various recommendations on two levels: the level of environmental educators and the level of policy makers. Also apparent for environmental educators was the importance of the student's individual capacity to learn from the situation itself and his or her flexible thinking - which needs to be developed not only in times of normalcy but also, and especially, in times of crisis. It is important to reflect on and draw specific conclusions based on personal experience and the experience of peers, especially in times of crisis. We suggest that teachers will make learning an iterative process, including ongoing awareness and discussions through a dynamic process, as opposed to a onetime activity (Beery, 2020). We also suggest further research on environmental educators' adaptation to the constant change in the educational agenda, which was characteristic of the COVID-19 pandemic, and on their ability to be open to the possibility of unplanned outcomes (Coleman \& MacDonald, 2020).

The findings are indicative of adaptations of teaching methods for distance learning that did not forfeit the advantages of active learning and outdoor learning. The teachers noted the importance of teamwork, which was lacking and challenging during the study. It is therefore necessary to find means of cooperation among environmental educators during times of crisis no less than during times of normalcy. According to the literature, it is important, especially during the pandemic, to prioritise collaborative work by teachers. That may occur through partnerships, peer learning and communities of practice as well as through fostering ongoing communication among school networks for sharing information about educational approaches (Azorín, 2020), particularly in the context of environmental education. In this sense, it is important to create teaching methods that incorporate nature and the environment in diverse ways through cooperative efforts among teachers from different subject areas. Specifically, taking advantage of international conduits of learning, by searching for and using media from around the world that deal with nature and the environment, may contribute to better teaching. This is consistent with the literature that suggests learning from and experimenting with coteaching and collaboration, as occurred during the pandemic (Ferdig et al., 2020).

For policy makers, collaboration between teachers and diverse methods of implementation may be things in which school principals and Ministry of Education supervisors should be engaged in developing. The frameworks necessary for sharing are difficult to produce in general, let alone in times requiring distance learning. In light of the opening up of various media conduits, it is now important to create a database of information and methods to make the material accessible to education professionals. We also recommend providing tools for outdoor teaching to educators who are not environmental educators in preparation for the next crisis. These tools include a variety of diverse outdoor practices that every teacher should know. 
For example, risk management in outdoor teaching can help teachers cope with such situations and should be acquired during training in pre-service teacher training institutions (Beery, 2020; Quay et al., 2020). Another example relates to teaching in situations of uncertainty, which is a skill that outdoor education teaches as a tool. Planning and being prepared for uncertainty have proven to be extremely important during the pandemic, emerging as a strategy for anticipating the unanticipated (Quay et al., 2020). The incorporation of outdoor teaching is no less important in times of crisis than it is in times of normalcy, as attested to by the environmental educators in this study. Despite the complexity of imparting outdoor teaching skills, such skills should be taught as part of the pre-service teachers training curricula and in-service teacher training, regardless of teachers' field of expertise.

It is also important to provide environmental educators with tools for online instruction that combine nature and the environment. Such tools can create learning experiences and interest among learners, as also attested to by the environmental educators in this study. In our study, environmental educators were able to use online materials and had the digital competence to do so. However, they needed more ways of incorporating nature into their teaching methods. According to the literature, teachers the world over need training programmes for developing better digital competency (Azorín, 2020).

The environmental educators emphasised the importance of being well-orientated in nature and viewing it as a source of calm, well-being, and the fulfilment of emotional needs aspects of nature that are familiar from the literature (Bratman et al., 2019; White et al., 2019). This was even more noticeable during lockdown, when people were limited in their ability to spend time in nature (Quay et al., 2020). The human inner-world needs support during times of crisis, meaning that incorporating nature and the environment has been even more valuable and significant during the pandemic than in normal times. It is also evident that protecting the environment requires incorporating personal and social well-being into the school curricula at all grade levels (lyengar, 2020). It is therefore important for policy makers to emphasise nature and the environment, especially during periods of crisis and stress like the one created by the COVID-19 pandemic (Collins et al., 2020; White et al., 2019).

One of our main recommendations for the education system is to allow educators autonomy. Educators in Israel need autonomy to enable them to develop creativity and to promote meaningful education, as did the environmental educators in this study. Affording autonomy to education professionals is important for facilitating creativity, incorporating nature and enabling the teacher to reach each student individually (Collie \& Martin, 2020; Reimers \& Schleicher, 2020).

The crisis period witnessed the production of various films dealing with natural phenomena in Israel. These videos served as a meaningful teaching method for environmental educators. In light of this fact, we recommend that in times of crises such as the COVID-19 pandemic, environmental organisations that deal with the interface and preservation of nature use products such as videos to help students and teachers establish a tie to the place and to nature and to derive enjoyment, even if it is mediated by screens. Our final recommendation is for education, culture and environmental groups to create conduits for unique learning and for facilitating a learning experience in which nature is "inserted" through the students' screens and the application of values of environmental education. We recommend that such organisations continue to create conduits of this kind - such as the planting of cameras in 
nesting boxes in zoos, videos from a safari and online lectures - to facilitate environmental education for all, not only in times of crisis but also in times of normalcy.

In conclusion, the findings indicate that teachers with experience in environmental education involving outdoor teaching largely possessed the tools necessary to carry out online teaching. Although they used diverse teaching methods during distance learning in a creative manner characterised by open thinking and reaction to learners, despite the limited feedback, not everyone was trained to use the necessary technological means. In light of this fact, we recommend providing all teachers in Israel with tools for environmental education that involves outdoor teaching and its online implementation. The education system must recognise that environmental education that involves outdoor instruction is a required skill, like critical thinking, high-order thinking and investigative learning - all of which are skills that have been defined as important for learners in the twenty-first century (Baird, 2019; Bell, 2010).

\section{REFERENCES}

Altomonte, S., Logan, B., Feisst, M., Rutherford, P. \& Wilson, R. 2016. Interactive and situated learning in education for sustainability. International Journal of Sustainability in Higher Education, 17: 417-443. https://doi.org/10.1108/IJSHE-01-2015-0003

Assunção, F.M. \& Gago, M. 2020. Teacher education in times of COVID-19 pandemic in Portugal: National, institutional and pedagogical responses. Journal of Education for Teaching, 46: 507-516. https://doi.org/10.1080/02607476.2020.1799709

Azorín, C. 2020. Beyond COVID-19 supernova. Is another education coming? Journal of Professional Capital and Community, 5: 381-390. https://doi.org/10.1108/JPCC-05-2020-0019

Baird, M. 2019. Project based learning to develop 21st century competencies. In R. Power (Ed.). Technology and the Curriculum: Summer 2019. Pressbooks.

Beery, T. 2020. What we can learn from environmental and outdoor education during COVID-19: A lesson in participatory risk management. Sustainability, 12: 1-12. https://doi. org/10.3390/su12219096

Bonnett, M. 2013. Sustainable development, environmental education, and the significance of being in place. Curriculum Journal, 24: 250-271. https://doi.org/10.1080/09585176.2013. 792672

Bell, S. 2010. Project-based learning for the $21^{\text {st }}$ century: Skills for the future. The Clearing house: A journal of educational strategies, Issues and Ideas, 83: 39-43. https://doi. org/10.1080/00098650903505415

Bratman, G.N., Anderson, C.B., Berman, M.G., Cochran, B., De Vries, S., Flanders, J., Folke, C., Frumkin, H., Gross, J.J. \& Hartig, T. 2019. Nature and mental health: An ecosystem service perspective. Science Advances, 5: 3-9. https://doi.org/10.1126/sciadv.aax0903

Colding, J. \& Barthel, S. 2019. Exploring the social-ecological systems discourse 20 years later. Ecology and Society, 24: 1-10. https://doi.org/10.5751/ES-10598-240102

Coleman, K. \& Macdonald, A. 2020. What are artists and art educators teaching us about how we can conceive and deliver teacher professional learning into the future? In R. Ferdig, E. Baumgartner, R. Hartshorne, R. Kaplan-Rakowski \& C. Mouza (Eds.). Teaching, Technology, and Teacher Education during the COVID-19 Pandemic: Stories from the Field. USA: Association for the Advancement of Computing in Education. 
Collie, R. \& Martin, A. 2020. Teacher wellbeing during COVID-19. ACER Teacher Magazine, $1-9$.

Collins, M., Dorph, R., Foreman, J., Pande, A., Strang, C. \& Young, A. 2020. A field at risk: The impact of COVID-19 on environmental and outdoor science education. The Lawrence Hall of Science, Policy Brief. Berkely, CA: University of California.

Creswell, J.W. 2012. Qualitative inquiry and research design: Choosing among five traditions, Thousands Oaks, CA: Sage Publication.

Daniel, J. 2020. Education and the COVID-19 pandemic. Prospects, 49: 91-96. https://doi. org/10.1007/s11125-020-09464-3

Denzin, N.K. \& Lincoln, Y.S. 2011. The Sage handbook of qualitative research. Thousand Oaks, CA: Sage.

Ferdig, R.E., Baumgartner, E., Hartshorne, R., Kaplan-Rakowski, R. \& Mouza, C. 2020. Teaching, technology, and teacher education during the COVID-19 pandemic: Stories from the field. United States: Association for the Advancement of Computing in Education.

Fereday, J. \& Muir-Cochrane, E. 2006. Demonstrating rigor using thematic analysis: A hybrid approach of inductive and deductive coding and theme development. International Journal of Qualitative Methods, 5: 80-92. https://doi.org/10.1177/160940690600500107

Folke, C., Carpenter, S.R., Walker, B., Scheffer, M., Chapin, T. \& Rockstrom, J. 2010. Resilience thinking: Integrating resilience, adaptability and transformability. Ecology and Society, 15: 1-9. https://doi.org/10.5751/ES-03610-150420

Hebebci, M.T., Bertiz, Y. \& Alan, S. 2020. Investigation of views of students and teachers on distance education practices during the Coronavirus (COVID-19) pandemic. International Journal of Technology in Education and Science, 4: 267-282. https://doi.org/10.46328/ijtes. v4i4.113

Huber, S.G. \& Helm, C. 2020. COVID-19 and schooling: Evaluation, assessment and accountability in times of crises - reacting quickly to explore key issues for policy, practice and research with the school barometer. Educational Assessment, Evaluation and Accountability, 32: 237-270. https://doi.org/10.1007/s11092-020-09322-y

lyengar, R. 2020. Education as the path to a sustainable recovery from COVID-19. Prospects, 49: 77-80. https://doi.org/10.1007/s11125-020-09488-9

Jauhariyah, M.N.R., Hariyono, E., Abidin, E.N. \& Prahani, B.K. 2019. Fostering prospective physics teachers' creativity in analysing education for sustainable development based curricula. JournalofPhysics:Conference Series, 1-10.https://doi.org/10.1088/1742-6596/1417/1/012086

Kidman, G. \& Chang, C.H. 2020. What does "crisis" education look like? International Research in Geographical \& Environmental Education, 29: 107-111. https://doi.org/10.1080/ 10382046.2020.1730095

Kolb, D.A. 2014. Experiential learning: Experience as the source of learning and development, US: Pearson FT press.

Krasny, M.E., Kalbacker, L., Stedman, R.C. \& Russ, A. 2015. Measuring social capital among youth: applications in environmental education. Environmental Education Research, 21: 1-23. https://doi.org/10.1080/13504622.2013.843647 
Krasny, M.E. \& Roth, W.M. 2010. Environmental education for social-ecological system resilience: A perspective from activity theory. Environmental Education Research, 16: 545558. https://doi.org/10.1080/13504622.2010.505431

Krasny, M.E. \& Tidball, K.G. 2009. Applying a resilience systems framework to urban environmental education. Environmental Education Research, 15: 465-482. https://doi. org/10.1080/13504620903003290

Krogh, E. \& Jolly, L. 2012. Relationship-based experiential learning in practical outdoor tasks. In A.E.J. Wals, \& P.B. Corcoran (Eds.). Learning for Sustainability in Times of Accelerating Change (pp. 213-224). The Netherlands: Wageningenin Academic Publishers.

Leal Filho, W., Raath, S., Lazzarini, B., Vargas, V., De Souza, L., Anholon, R., Quelhas, O., Haddad, R., Klavins, M. \& Orlovic, V. 2018. The role of transformation in learning and education for sustainability. Journal of Cleaner Production, 199: 286-295. https://doi.org/10.1016/j. jclepro.2018.07.017

Löf, A. 2010. Exploring adaptability through learning layers and learning loops. Environmental Education Research, 16: 529-543. https://doi.org/10.1080/13504622.2010.505429

Mcphearson, T. \& Tidball, K.G. 2013. Disturbances in urban social-ecological systems: Niche opportunities for environmental education. In M. Krasny \& J. Dillon (Eds.). Trading zones in environmental education: Creating transdisciplinary dialogue (Re-Thinking Environmental Education). New York: Peter Lang Publishing.

Miles, M.B. \& Huberman, M. 1994. Qualitative data analysis: An expanded sourcebook. Thousand Oaks, CA, Sage Publication.

Passy, R., Bentsen, P., Gray, T. \& Ho, S. 2019. Integrating outdoor learning into the curriculum: an exploration in four nations. Curriculum Perspectives, 39: 73-78. https://doi.org/10.1007/ s41297-019-00070-8

Perlman, M., Howe, N. \& Bergeron, C. 2020. How and why did outdoor play become a central focus of Scottish early learning and care policy? Canadian Journal of Environmental Education, 23: 46-66.

Pizmony-Levy, O. 2018. Compare globally, interpret locally: international assessments and news media in Israel. Globalisation, Societies and Education, 16: 577-595. https://doi.org/10 $.1080 / 14767724.2018 .1531236$

Plummer, R. 2013. Social-ecological resilience and environmental education: Synopsis, application, implications. Resilience in Social-Ecological Systems. London: Routledge.

Quay, J., Gray, T., Thomas, G., Allen-Craig, S., Asfeldt, M., Andkjaer, S., Beames, S., Cosgriff, M., Dyment, J.E. \& Higgins, P. 2020. What future/s for outdoor and environmental education in a world that has contended with COVID-19? Journal of Outdoor and Environmental Education, 23: 93-117. https://doi.org/10.1007/s42322-020-00059-2

Reimers, F.M. \& Schleicher, A. 2020. A framework to guide an education response to the COVID-19 Pandemic of 2020. Paris: OECD.

Sagy, G. \& Tal, A. 2015. Greening the curriculum: Current trends in environmental education in Israel's public schools. Israel Studies, 20: 57-85. https://doi.org/10.2979/israelstudies.20.1.57

Saldaña, J. 2009. The coding manual for qualitative researchers, Thousand Oaks, CA, Sage Publication. 
Sammalisto, K., Sundström, A. \& Holm, T. 2015. Implementation of sustainability in universities as perceived by faculty and staff - a model from a Swedish university. Journal of Cleaner Production, 1: 45-54. https://doi.org/10.1016/j.jclepro.2014.10.015

Seidman, I. 2012. Interviewing as qualitative research: A guide for researchers in education and the social sciences, NY, Teachers College Press.

Sjöblom, P. \& Svens, M. 2019. Learning in the Finnish outdoor classroom: Pupils' views. Journal of Adventure Education and Outdoor Learning, 19: 301-314. https://doi.org/10.1080/ 14729679.2018.1531042

Sterling, S. 2010. Learning for resilience, or the resilient learner? Towards a necessary reconciliation in a paradigm of sustainable education. Environmental Education Research, 16: 511-528. https://doi.org/10.1080/13504622.2010.505427

Tal, T. 2020. Green schools in Israel: Multiple rationales and multiple action plans. In A. Gough, J.C-K. Lee \& E.P.K. Tsang (Eds.). Green Schools Globally. Switzerland: Springer. https://doi. org/10.1007/978-3-030-46820-0_13

Tal, T., Lavie-Alon, N. \& Morag, O. 2014. Exemplary practices in field trips to natural environments. Journal of Research in Science Teaching, 51: 430-461. https://doi.org/10.1002/ tea. 21137

Tidball, K.G. \& Krasny, M.E. 2010. Urban environmental education from a social-ecological perspective: Conceptual framework for civic ecology education. Cities and the Environment, 3: 1-11. https://doi.org/10.15365/cate.31112010

Tidball, K.G. \& Krasny, M.E. 2011. Toward an ecology of environmental education and learning. Ecosphere, 2: 1-17. https://doi.org/10.1890/ES10-00153.1

Walker, B., Holling, C.S., Carpenter, S.R. \& Kinzig, A. 2004. Resilience, adaptability and transformability in social--ecological systems. Ecology and Society, 9: 5-10. https://doi. org/10.5751/ES-00650-090205

White, M. P., Alcock, I., Grellier, J., Wheeler, B.W., Hartig, T., Warber, S.L., Bone, A., Depledge, M.H. \& Fleming, L.E. 2019. Spending at least 120 minutes a week in nature is associated with good health and wellbeing. Scientific Reports, 9: 1-11. https://doi.org/10.1038/ s41598-019-44097-3

Wimberley, E.T. 2009. Nested ecology: The place of humans in the ecological hierarchy. Maryland, US: Jhon Hopkins University Press. 